\title{
The Business of Surgery
}

\section{Medicine, Money and Morality}

Ovariotomy was the product of a medical culture that had a convoluted relationship with money. Two differing ideas regarding doctors' financial interests had long been present within the profession. One was that doctors should be impartial providers of the best possible care for their patients, motivated primarily by humane and altruistic concerns. The other was that they were men of trade, profiting financially from attending the sick. It was a dichotomy that had first been explicitly clarified in Britain by the Scottish physician John Gregory in his popular guide to ethical doctoring, Observations on the Duties and Offices of a Physician (1770). Gregory did not necessarily see these two identities as incompatible. ${ }^{l}$ But that such a distinction could be made was to factor into one of the most complex quandaries nineteenth-century doctors faced: how to make money while retaining a moral foundation to one's practice. As Gregory's work suggests, this concern was not new to the Victorian era. But by the middle decades of the nineteenth century, rhetorical strategies were increasingly being employed by doctors to prise medicine away from any notion of it being motivated by personal gain. This was part of a wider move towards driving out medical corruption in all its forms, and establishing a more regulated profession. ${ }^{2}$ Increasingly, as the ethics around money-making in medicine began to be realigned, medical practitioners were drawn into a torturous relationship with their

(C) The Author(s) 2018

S. Frampton, Belly-Rippers, Surgical Innovation and the Ovariotomy

Controversy, Medicine and Biomedical Sciences in Modern History, https://doi.org/10.1007/978-3-319-78934-7_5 
finances, as growing constraint was put upon discussion of money. And yet, every individual doctor remained deeply in the thrall of economic circumstance. ${ }^{3}$

With the 'rise' of social history in the late twentieth century and that discipline's prevailing concern with class and material wealth, historians of medicine have been attentive to the relationship between medicine and money with its complexities, confusions and occlusions. In relation to surgery, historian Sally Wilde has rightly concluded that it is unsatisfactory to consider the economics of surgery as 'driven exclusively by the logic of market forces', and argues that the influence of the moral economy must be examined too. ${ }^{4}$ Yet aside from Wilde, economic work on the history of surgery, especially in its nineteenth-century context, has been scant. The historiographic trend towards scrutinising divisions (or lack thereof) between 'orthodox' and 'unorthodox' practitioners, and in thinking about the commercialisation of medicine through the prism of patent medicines, has generated significant work. ${ }^{5}$ But as a trend it also suggests historians have been embedded in - perhaps even confused by-the Victorian profession's guarded attitude towards money matters. To focus upon patent medicines, devices, advertising and other of medical men's forays into explicitly commercial medicine is to draw away from explorations of the implicit role money played in all areas of medicine-including operative surgery. It reinforces an arbitrary division between commercial and non-commercial forms of medicine when, in reality, all modes of medical practice had some kind of relationship to commerce. Dig a little deeper, and the question of pecuniary gain permeates professional discourse; money was everywhere, even where its presence was not immediately obvious. ${ }^{6}$

Ovariotomy was closely embedded in this moral-economic nexus and its financial implications were of particular importance in the last twentyfive years of the century when the operation came to be definitively recognised as a successful and perhaps even revolutionary procedure. It was a time when a great deal else was happening in the field; the introduction of antiseptics had an influential effect on surgery, although as we shall see, its use in ovariotomy was greatly contested. There was also increasing concern about the overuse of the operation, something which has been well addressed by historians, but which requires a more critical examination of the financial implications entangled within it. Thus, the intention of this chapter is to offer a new approach to the period by setting the expansion of the operation within a discourse of trade and business, rather than reading it solely through changing notions of 
female pathology—although the two concerns were by no means separate. Increasingly, ovariotomy was understood as an innovation of specialist and private practice, as those who performed the operation began to be identified (and identified themselves) as specialist 'ovariotomists'. It could also be an expensive operation and its price was determined by a multitude of factors, some of which were closely connected to its status as an innovative procedure. Its value was also entwined with broader debates that were occurring in the profession as to the need for more regulation and guidance in relation to professional income. In the 1880s and 1890s, in Europe and America, ovariotomy was derided by some as a 'fashion', as growing concerns were voiced regarding the frequency with which ovarian operations were being performed. This led to troubling questions regarding the impact of ovariotomy's remunerative nature upon medical authority. 'Ovariotomies are a source of income; many have grown rich on them and you strike at the root of a very thriving industry', wrote one correspondent to the Journal of the American Medical Association in 1896, responding to a critique of the operation. ${ }^{7}$ Was it possible, as commentators inferred, that ovariotomy had become nothing more than a business? By the end of the century, this question was coming to dominate discourse around the operation, as its respectability and justifiability were once more called into question.

\section{The Operator Becomes the Ovariotomist: Specialism and Private Practice}

The mid-to-late nineteenth century is usually characterised as a period that saw the 'rise' of hospital medicine; that is, that medical theory, practice and innovation became centred within the walls of the large general hospitals. ${ }^{8}$ Surgical advance in particular has been closely linked to the changes brought about by the establishment of antiseptic and aseptic techniques in the 1870s and 1880s, and especially the germ theory and wound management system of Joseph Lister, which in itself informed late nineteenth-century visions of the hospital space as a locale of cleanliness and social order. ${ }^{9}$ Lister himself saw the decline in hospital fever (hospital-acquired infection) as his most important achievement. ${ }^{10}$

The idea, once pervasive, that Lister's theory and practice constituted a rapid and uncontested 'revolution' in surgery has been dispelled by historians. It is clear that not only did Lister himself frequently modify his 
system, but many surgeons were either sceptical of his theories or, as was more often the case, his practice. ${ }^{11}$ Many failed to see what was novel or innovative about his system, when the majority of surgeons already employed scrupulous aseptic techniques in their practice. ${ }^{12}$ Ovariotomy frequently featured in these debates. While many ovariotomists used and even championed Lister's techniques, in no other field of surgery was the usefulness of the antiseptic system more fiercely contested. Some practitioners expressed doubts about the effectiveness of the system when used within the abdomen. The peritoneum-the membranous covering of the abdominal cavity - was known to have rapid absorbing qualities, and if the peritoneum was found to be in a healthy state upon opening the abdomen, the combination of a drainage tube and the tissue's natural absorption mechanism was seen as sufficient in preventing any build-ups of fluid that could lead to putrefaction, a view even Lister himself appeared to have endorsed. ${ }^{13}$ Even more persuasive to opponents of Listerian antisepsis was the fact that operators like Thomas Keith in Edinburgh had had great success with ovariotomy some time before the introduction of carbolic acid for the treatment of surgical wounds. Keith was a quiet, guarded man who rarely involved himself in the controversies of the day, not least one that involved his friend and contemporary Joseph Lister. But in a letter to the British Medical Journal in 1878, Keith set out his position. While believing that antiseptics, overall, had improved his results, he argued that technical developments like the use of drainage tubes, the wide-scale application of the cautery (rather than the clamp) when treating the pedicle, and the introduction of compression forceps had been of equal importance in precipitating a declining mortality rate for ovariotomy. ${ }^{14}$ Other prominent practitioners of the operation were, however, more damning in their assessment of antiseptics. Robert Lawson Tait, for example, was an avowed opponent of the Listerian system of surgery.

Debates about technical developments in antiseptics only barely masked the fact that claims to the professional landscape-and its pecuniary rewards-were at stake. A source of particular tension was the relationship between ovariotomy, innovation and hospital medicine. Ovariotomies were increasingly performed in general hospitals towards the end of the century. But up until the 1890s, the majority of ovarian operations still continued to take place in private lodgings (including patients' homes) or in smaller specialist hospitals for women, the latter of which included both charitable and private institutions. ${ }^{15}$ 
This was reflected in the professional positions of those who had become pre-eminent in the field: both Thomas Spencer Wells at the Samaritan Free Hospital and Robert Lawson Tait at the Birmingham and Midland Hospital for Women retained their high status without ever having an appointment at one of the large teaching hospitals. Charles Clay had resigned his position at St. Mary's Hospital in Manchester in 1858 after just one year, due, he claimed, to the burden of his private practice, and never had a hospital affiliation again, even a specialist one. Although his lack of institutional work would lead to his respectability later being questioned by Wells, as described in Chapter 4 , it did little harm to his local reputation and practice, the latter of which remained sizeable. ${ }^{16}$ Many specialists in ovarian disease, including George Granville Bantock, Wells' successor at the Samaritan, Thomas Keith and Lawson Tait also set up private nursing homes for their ovariotomy patients. ${ }^{17}$

As the Manchester practitioner David Lloyd Roberts-who made a fortune out of his practice in ovariotomy-once quipped, it seemed that 'a hospital was useful to a man during the first ten years on the staff; during the second ten years, honours were about equal; during the third ten years the man was useful to the hospital'. ${ }^{18}$ Charitable hospitals, which paid their medical staff nothing more than an honorarium, were only ever one arrow in the quiver of the successful doctor, providing prestige, honour and clinical material to complement the private work through which they made their money. As the careers of practitioners progressed, they often became increasingly immersed in private practice. Wells was a case in point: he retired from the Samaritan in 1877 aged fifty-nine, but his private practice flourished for another decade, his reputation both as a charitable and skilful operator established enough that he could focus on private cases. The career trajectories of the top ovariotomists support the observation made by Marguerite Dupree and Anne Crowther that during this time 'specialists' in diseases of women and in obstetrics were especially notable for their tendency to remain attached to smaller hospitals throughout their career and, in general, were less dependent on appointments at larger, charitable institutions for the provision of social cachet. ${ }^{19}$

The understanding that ovariotomists were specialists had important currency in medical politics, as debates raged in the profession as to the value of specialist practice in general. Medical specialists of all kinds, particularly those who set up their own institutions, had long faced hostility from within the profession. Many practitioners continued to ascribe to 
the idea that hospitals which catered to specific types of disease were little more than money-making ploys, ostensibly charitable, but in fact set up only to gain the patronage and support of the rich, who could then be used to gain a precious foothold in the market for private practice. Those who described themselves as specialists in diseases of women were often considered the most avaricious of all. ${ }^{20}$ A pamphlet which appeared in 1877, wittily entitled Contradiction! Or English Medical Men and Manners, authored by a practitioner named James O'Flanagan, reserved particular venom for specialists in female disease. O'Flanagan played on the word 'speculum', the instrument used to make vaginal examinations, to insinuate the unsavoury financial aspects to this particular specialist's relationships with their patients:

If named after his occupation he would have - as in some other trades he has - the amiable title of "ladies' man". I propose however, to call this gentleman the speculum specialist......from nervousness or indigestion or hysteria, and certain deranged functions, a woman gets it into her head that she is a subject for the speculum. She sets out, is "speculated" upon, and re-returns to the operation with periodicity in recurrence equal to a complete repetend in circulating decimal fractions. ${ }^{21}$

Despite these connotations of impropriety, as ovariotomy became more successful, those who performed it became confident in-and increasingly protective of - the operation's status as a specialist procedure. Indeed, in the eyes of those practitioners who saw the development of specialism in medicine as a sign of growing maturity in the profession, ovariotomy was a prime example of a genuine innovation that had emanated from private and specialist practice and not from the larger hospitals, whose emphasis on the systematic management of large numbers of patients was viewed as a hindrance to innovation rather than a catalyst. 'Are the triumphs of ovariotomy and abdominal section to be reckoned among "the great advancements" which have come from general hospitals?' wrote the laryngologist and ardent advocate of specialism, Morell Mackenzie in 1885, 'the fact is that a general hospital is about the last place from which one would naturally expect any striking innovation to come. Such institutions are from the conditions of their existence schools of routine'. ${ }^{22}$

Many ovariotomists wished to see the procedure retain a distinctive identity, performed only by those with 'special' skill in the area. This was 
in part a response to technical concerns: the alleged incompatibility of ovariotomy with Listerian antisepsis, claimed by some surgeons, seemed to clarify continued, fundamental differences between surgery that ventured into the abdomen and that which did not. But layered upon this were deep-seated professional and financial implications. Much to the chagrin of some specialists, general hospital surgeons were increasingly asserting their right to perform the operation, arguing that antiseptics and the general move towards scrupulous cleanliness had had a democratising effect on ovariotomy, opening the abdomen to all who practised clean, safe surgery. As Ornella Moscucci has highlighted, the economic implications of this were clear: if general hospital surgeons took up the operation with regularity, they would eventually gain a foothold in the market for private ovariotomies too. ${ }^{23}$

It was perhaps for these reasons that the term 'ovariotomist' was one increasingly used in the medical press during the 1880s. ${ }^{24}$ Along with 'lithotomist' it was one of the few titles used to denote an operator's special skill at one particular operation. The way the term was used was varied and not always clear-cut. Occasionally it meant anyone who performed ovariotomy; after all, surgeons were, by this point, generally expected to be trained in and ready to perform the operation if necessary in an emergency situation, an operation as essential to the young surgeon's repertoire as amputation, lithotomy or ligation. It was also on occasion a label thrust upon others with derogatory connotations, particularly in the early days of the operation. But for the most part 'ovariotomist' was a term of self-identification used with pride by those who performed ovariotomies frequently. It referred to a particular identity: those who considered themselves and were considered by others as especially skilled and experienced in the operation. By sculpting a reputation for specialist surgical skill, successful ovariotomists were also able to manoeuvre themselves into the surgical elite, in spite of their professional rivalries with general surgeons. This was especially the case for ovariotomists practising in London, many of whom played important roles in the city's surgical societies. ${ }^{25}$ Thus, as British medicine began to remould itself into a bifurcate model of 'consultants' (those who were in the elite of 'pure' physicians and surgeons) and general practitioners, ovariotomists slipped easily into the former group. As Dupree and Crowther have argued, this division between general practitioner and consultant was not necessarily one with any definitive demarcations of practice; a reputation as a surgical 'consultant' was cultivated rather than acquired 
with any inevitability. Nor was a definition of surgical skill set in stone; rather understandings of skill were heavily dependent on their context and often re-imagined depending on the individual characteristics and motivations of prominent surgeons of the day. ${ }^{26}$ Asserting surgical skill, it is fair to say, was often in part a rhetorical device and not always an exact reflection of technical proficiency. It was not unusual for obituaries and biographical recollections of elite surgeons in the late nineteenth century to note a relative lack of technical ability on the subject's part, suggesting the importance of other qualities like sociability, personality and a carefully cultivated reputation for intellectualism that could equally play a role in propelling one to the higher echelons of the profession. ${ }^{27}$ Thomas Spencer Wells' assistant at the Samaritan Hospital, Alban Doran, for example, despite being a successful ovariotomist, was described in one obituary as 'having no surgical hands' but was remembered as a 'learned and accurate litterateur'. ${ }^{28}$ And yet to attain a position as a consultant-level practitioner had significant financial implications. Elite surgeons could build lucrative practices, trading on their reputation and standing. This was perhaps nowhere more so the case than in the practice of ovariotomy, where the financial rewards could be significant.

\section{Surgical Fees: Determining the Cost of Ovariotomy}

The suggestion that ovarian surgery was especially remunerative was present from its beginnings and in the earlier days of the operation it was an association that was almost invariably negative. No one had emphasised the operation's connection with money more so than its staunchest critic, Robert Lee. In 1862, when Lee was still actively denouncing the operation, and at one of the many meetings around this time where practitioners argued over its justifiability, the obstetrician had declared that 'the question now under discussion was a money question, and not one of science and humanity'. Lee defended this claim by producing anecdotal evidence that at least one English ovariotomist had charged the rather extraordinary sum of three hundred guineas for an operation performed in Ireland, and had expected a hundred guineas each day afterwards that he was to be in attendance. Lee reported that the operation had resulted in the death of the patient just eighteen hours later. $^{29}$

While Lee could well have been exaggerating the fees demanded in this particular case, they were by no means figures pulled out of the air. Although a private ovariotomy could be purchased for as little as five 
guineas, if you were lucky enough to find a surgeon willing to perform on poorer cases, fees for private ovariotomies in London and in the major metropolitan cities could easily stretch to a hundred guineas. ${ }^{30}$ Indeed, this appears to have been the accepted price for an ovariotomy from around the 1860s until at least the mid-1880s. ${ }^{31}$ Given the oblique manner in which doctors discussed money, few ovariotomists directly addressed the question of how much they earned. But this did not prevent the subject being speculated upon in the medical press, although noticeably more so in the pages of the American journals than the British, as in the former, doctors' finances were more openly discussed. As The American Practitioner put it in 1877, rumour had it that Thomas Spencer Wells did 'not lift a knife for less than one hundred guineas'-a claim that Wells never directly denied. ${ }^{32}$ As Ornella Moscucci has shown, such a fee was about equal to the annual income of a doctor in the early years of their practice, thus underscoring the appeal the operation might have held for a young practitioner. ${ }^{33}$

Extending this comparison with wages into the broader economic context of nineteenth-century income, one gains an understanding of just how expensive a private ovariotomy was. One study of nineteenth-century wages has posited the average annual income in 1871 for an engineer at around $£ 579$, that of a Government employee at around $£ 281$ and that of a schoolmaster at just $£ 97 .{ }^{34}$ It seems likely, then, that most sufferers of ovarian disease seeking surgery would have been priced out of the private market and that for all but the reasonably well-off, the services of a charitable institution would need to be sought instead, be it one of the larger hospitals or, as was more likely, through the charity of a specialist institution like the Samaritan Hospital. A supplement that appeared in the Lancet in 1886 as part of a Hospital Sunday Fund appeal, and likely aimed towards the wider public, seems to confirm this. The appeal claimed that every hospital-based ovariotomy cost the institution a sizeable $£ 10$, mainly because of the amount and intensity of nursing that was required after an ovariotomy was completed. ${ }^{35}$ Keen to draw attention to the amount of surgical work that was dependent on charity, the appeal noted that in the case of ovariotomy, 'except with well-to-do people, the doctors mostly recommend the hospital'. ${ }^{36}$

Thus, while the private ovariotomy market was lucrative it was also small; to pursue a career as an ovariotomist was a high-risk strategy in terms of regular income generation. Practitioners were nonetheless cognisant of the appeal that brilliant operations could retain among their younger brethren, especially in comparison with the more routine work 
of minor operations and obstetrical deliveries. Besides which, the operation was now safer than it had ever been. So much so that Thomas Keith was moved to remark in 1878 that it almost makes one envy the younger ovariotomist to whom the way in these days is made easy', calling into question the assertion of specialists that ovariotomy still required a specific skill set. ${ }^{37}$ The appeal of ovariotomy rested on its dramatic history and the operation continued to engender a sense of daring, of singularity, of being something special. It was a combination of factors that gave performers of the operation a visible authority. Major operative surgery, with its sense of urgency and drama, had an electric impact. ${ }^{38}$ It could offer a potential one-off quick fix for chronic conditions that made patients miserable and socially isolated. It was precisely in these terms that surgeon and ovariotomist Isaac Baker Brown framed a successful surgical case in 1865 that had taken place at the London Surgical Home for Women, an institution set up by Brown in 1858, where patients paid fees according to what they could afford. Conveying a sense of desperation on the woman's part, Brown recounted how she had:

Spent her substance in obtaining medical aid, but God had not seen fit to give her relief. She was a patient sufferer truly, and a great invalid when she came into this Home. I said to her "I think I can cure you, but the operation is new; it is almost experimental" she replied - "Do what you like;" and I think her expression was "Cut me to pieces, if you can cure me." 39

Nowhere more so was this drama apparent than with ovariotomy, where the change in condition - the removal of a large tumour-was immediately noticeable to the patient and her friends and family. This had numerous economic implications. Specifically, it meant ovariotomists could imply that their services, despite their high prices, were actually a more financially sensible option than continually resorting to medical palliatives. More broadly one can speculate upon the appeal that specialising in ovariotomy would have had in what was a rather gloomy economic climate in Britain in the 1870s and 1880s. Most economic historians agree that if there was not a depression per se, the 1870 s did see a tailing off of the economic boom that had characterised the mid-century, when new technological industries had rapidly expanded. ${ }^{40}$ As a result, the 1870s and 1880s were times of comparatively slow growth. Doctors were aware of this and worried about the consequences of commercial depression upon their profession. This showed itself in renewed anxieties 
about overcrowding, much of which centred upon the idea that medical schools were overfilled with unsuitable students, men who in brighter economic circumstances would have gone into business and industry, but who were instead entering into an already overcrowded profession, selecting medicine because of a dearth of other opportunities. ${ }^{41}$ Medicine, it was feared, was increasingly viewed in stark economic terms by young men as the profession which would give the quickest financial return. ${ }^{42}$ With the passing of the 1876 Medical Act, which allowed women to qualify as doctors in Britain, fears were further stoked about increased crowding and competition from women, particularly for female patients, which might lead to male doctors' income being reduced. ${ }^{43}$

How much substance there was to claims about overcrowding is debatable, but the spectre of it touched a raw nerve in doctors. Economic questions began to place high on the agenda of the weekly medical press. ${ }^{44}$ Many felt that, disproportionately to other occupations, those in the medical profession were not sufficiently rewarded for their services, and that their fees were incompatible with their status as men of culture and refinement. ${ }^{45}$ It compelled medical men to address an issue that it could be difficult to talk about openly without risking accusations of impropriety: making money. Of particular concern was the damage inflicted by the tradition of the annual billing system that most practitioners worked under and which, as Anne Digby has shown, often resulted in large patient debts remaining unpaid for long periods of time, if not permanently. ${ }^{46}$ This frequently left doctors having to chase down their debtors in a manner considered undignified to the learned practitioner. The crudeness of the financial exchange was a perennial concern in the profession. What marked out the debates emerging in the $1870 \mathrm{~s}$ was concern over correctly identifying the value of medical and surgical services. ${ }^{47}$ The British Medical Journal became the central focus point for this campaign and the journal pushed for the British Medical Association to produce a thoroughly investigated, standardised scale of fees to counteract the generic prices for medical services usually charged, which did little to connect specific financial values to different services. In 1878, the British Medical Journal wrote that:

It is somewhat disgusting for the professional mind to have to discuss fees at all. This sentiment is materially expressed by the piece of paper in which the fee is habitually wrapped, and the tacit manner in which it is paid. But advantage should not be taken of this attempt to bind professional men to the uniform acceptance of an insufficient payment for services of very various value. ${ }^{48}$ 
Practitioners wrote in to express gratitude to the journal for vocalising a taboo subject. As one grateful correspondent put it, 'I feel sure you have struck off once and for all the galling fetter of the uniform guinea-fee'. ${ }^{9}$

The British Medical Association itself never produced a definitive scale of fees. But various other medical societies did, some of them affiliated branches of the Association. These scales were often limited in their coverage and especially so in relation to surgery. In their tariff of medical fees issued in 1879 for example, the Manchester MedicoEthical Association refused to make a judgment regarding the costs of surgery, including suggested fees only for general practitioners and consulting physicians' visits and advice. 'The Association cannot undertake to define individual skill or reputation in this respect', it decreed. This remained the case throughout the editions of the tariff produced in the following decades. ${ }^{50}$ The reluctance to judge the financial value of operations perpetuated the idea of surgical skill as esoteric, its value beyond the judgment of those outside the surgical profession. It also left a nebulous gap in the pricing of major operations, in which the value of different procedures was left to be self-defined by surgeons, suggesting how much more lucrative surgery could potentially be compared to medicine.

But why, some observers reasoned, construct scales of fees only for surgery to be left out? There was a vague understanding among practitioners that all operations which imposed a serious risk to life-ovariotomy, lithotomy and major amputations - should cost at least a hundred guineas, and many felt that leaving prices to individual judgement was not desirable. ${ }^{51}$ In 1874 there appeared the first tariff in Britain that addressed the issue. The pamphlet, titled The Medico-Chirurgical Tariffs (Fig. 5.1), was authored by Jukes de Styrap, a general practitioner who would later solidify his reputation as an authority upon issues of medical morality with his well-known work $A$ Code of Medical Ethics (1878). ${ }^{52}$ Written on behalf of the Shropshire branch of the British Medical Association and with four further editions produced, The Medico-Chirurgical Tariffs was the first of its kind to include a suggested scale of operative fees. ${ }^{53}$ Prices were given for over sixty surgical operations and the pamphlet was envisioned as a guide to general practitioners as well as younger physicians and surgeons starting out in their career. Thus, the prices given were considerably lower than those that London consultants were charging. Indeed, to the disappointment of some reviewers, de Styrap, like others, had avoided 


\begin{tabular}{|c|c|c|c|}
\hline General Surgical. Practitioners. & Minimum. & $\begin{array}{l}\text { Medium } \\
\text { Fees. }\end{array}$ & Maximum. \\
\hline For the Talicotian Operation $\quad \ldots$ & $\begin{array}{rrr}6 & \text { s. } & \text { d. } \\
5 & 5 & 0\end{array}$ & $\begin{array}{l}6 \text { s. d. } \\
\text { to }\end{array}$ & $\begin{array}{ccc}6 & \text { s. } & \text { d. } \\
21 & 0 & 0\end{array}$ \\
\hline $\begin{array}{l}\text { For the operation for the removal of a } \\
\text { Naevus or Aneurism by Anastomosis }\end{array}$ & $\begin{array}{lll}1 & 1 & 0\end{array}$ & & $\begin{array}{lll}5 & 5 & 0\end{array}$ \\
\hline $\begin{array}{c}\text { For the operation for the removal of } \\
\text { Cicatrices }\end{array}$ & & & $5 \quad 50$ \\
\hline For the operation of Dermic-Grafting $\ldots$ & 106 & & $\begin{array}{lll}3 & 3 & 0\end{array}$ \\
\hline For the operation for Cleft-Palate $\quad .$. & $\begin{array}{lll}5 & 5 & 0\end{array}$ & & 15 150 \\
\hline For the operation for Hare-Lip ... & 220 & & 10 10 0 \\
\hline For the removal of Polypus Nasi... ... & 106 & $\Xi \stackrel{\Xi}{\exists}$ & $5 \quad 50$ \\
\hline $\begin{array}{c}\text { For the removal of Foreign bodies from } \\
\text { the Ear, Eye, Nose, Pharynx, or } \\
\text { Esophagus }\end{array}$ & 106 & 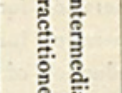 & 220 \\
\hline For the operation of Tracheotomy $\quad \ldots$ & $\begin{array}{lll}3 & 3 & 0\end{array}$ & $\stackrel{9}{\Rightarrow}$ & 10 100 \\
\hline For the introduction of the Stomach Pump & $1 \cdots 1 \quad 0$ & . & 330 \\
\hline $\begin{array}{cccc}\text { For the operation of } & \text { Trocar-Suction-or } \\
\text { 'Aspiration' } & \ldots & \ldots & \ldots\end{array}$ & $\begin{array}{lll}1 & 1 & 0\end{array}$ & 高 & $5 \quad 50$ \\
\hline For Paracentesis Thoracis ... $\quad \ldots \quad \ldots$ & $2 \cdots 2 \quad 0$ & $\overrightarrow{3} \cdot \vec{z}$ & $5 \quad 50$ \\
\hline For Paracentesis Abdominis & $1 \quad 1 \quad 0$ & 点 & $\begin{array}{lll}5 & 5 & 0\end{array}$ \\
\hline For the reduction of Hernia by Taxis .... & $1 \cdots 10$ & 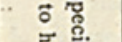 & 550 \\
\hline For the operation for Strangulated Hernia & $\begin{array}{lll}5 & 5 & 0\end{array}$ & 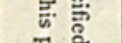 & I5 150 \\
\hline For the operation of Cholecystotomy & 5.56 & $\ddot{\ddot{E}}$ & 2100 \\
\hline tion of Colotomy $\ldots$ & $\begin{array}{lll}5 & 5 & 0\end{array}$ & $\stackrel{2}{g}$ & 15150 \\
\hline For the operation of Duodenostomy & 5.50 & $=\frac{3}{3}$ & 2100 \\
\hline For the operation of Enterostomy & $\begin{array}{lll}5 & 5 & 0\end{array}$ & है ङ & is 150 \\
\hline For the operation of Gastrostomy & $5 \cdot 5 \quad 0$ & 0 & $\begin{array}{lll}15 & 150\end{array}$ \\
\hline For the operation of Hysterectomy & 10 100 & $\overrightarrow{\vec{R}}$ & 2100 \\
\hline For the operation of Laparotomy... & $\begin{array}{lll}5 & 5 & 0\end{array}$ & $\stackrel{n}{\circ}$ & 2100 \\
\hline For the operation of Laryngotomy & $\begin{array}{lll}3 & 3 & 0\end{array}$ & 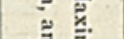 & io 100 \\
\hline For the operation of Lithotomy ... & 10100 & $\overrightarrow{\mathrm{E}} \mathrm{\Xi}$ & 2650 \\
\hline For the operation of Lithotrity $\ldots$ & $5 \cdot 50$ & $\Xi$ & $26 \quad 50$ \\
\hline For the operation of Nephrotomy & 10 100 & 常 & 2100 \\
\hline For the operation of Esophagotomy & $\begin{array}{lll}3 & 3 & 0\end{array}$ & $=\varnothing$ & 10100 \\
\hline For the operation of Ovariotomy.... & 15150 & 悉 & $\begin{array}{l}31 \text { 10 } 0 \\
\text { and upwasds. }\end{array}$ \\
\hline Far the operation of Pneumotomy & $\begin{array}{lll}5 & 5 & 0\end{array}$ & $\vec{z}$ & 15 is: 0 \\
\hline For the operation of Prostatectomy & $\begin{array}{lll}3 & 3 & 0\end{array}$ & & 10 , 10 \\
\hline For the operation of Pylorectomy & $\begin{array}{lll}5 & 5 & 0\end{array}$ & & 15150 \\
\hline For the operation of Splenotomy.... .... & 10.100 & 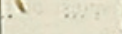 & 2650 \\
\hline
\end{tabular}

Fig. 5.1 Table taken from the fifth edition of Jukes de Styrap's The MedicoChirurgical Tariffs, a popular reference manual for general practitioners and young surgeons and physicians, published in 1890. Even though ovariotomy was no longer new, it remained more expensive than comparatively riskier operations such as hysterectomy, nephrotomy or splenotomy, and was the only operation to appear on de Styrap's extensive list with a note in the maximum fee column that suggested an almost unlimited price tag upon a private procedure, denoted by the insertion of 'and upwards' (Credit Wellcome Collection CC BY) 
suggesting prices that doctors of consultant level might charge, where pricing remained at the discretion of the practitioner. ${ }^{54}$ Nonetheless de Styrap's pamphlet was warmly welcomed by the profession. As the Edinburgh Medical Journal put it, de Styrap's work taught 'the young practitioner promptitude, business habits, and consideration both for his own position and the circumstances of his patient' ${ }^{55}$ Reconceptualising fees was not just about getting the 'right' price but about efficient management of medical practice. This was connected to a broader shift in late nineteenth-century medicine towards managerial efficiency, inspired in part by the increasingly important role of administration and management in hospitals. ${ }^{56}$

De Styrap's work served not only to clarify just how remunerative ovariotomy was but, as it was produced by a branch of the British Medical Association, to morally authenticate it being so. In the 1890 edition, de Styrap suggested as a general guide that ovariotomies were to be charged at between ' $£ 15 / 15$ and $£ 31 / 10$ and upwards' and throughout the editions of the pamphlet, ovariotomy and caesarean section were deemed by de Styrap to be the most expensive operations in surgery. ${ }^{57}$ But de Styrap also pointedly demarcated between ovariotomy and caesarean section by his use of the phrase 'and upwards' after the suggested price for ovariotomy, seemingly giving practitioners a licence to charge whatever they wanted for the operation. To no other operation or service in his table did de Styrap apply those two telling words. This was despite the appearance by then of operations which were arguably riskier than ovariotomy; splenotomy (incision into the spleen) for example, which had only been introduced into practice in the mid-1880s, was given a suggested price of between $£ 10$. 10 s and $£ 26$. 5s, while nephrotomy (an incision into the kidney), also new and risky, was priced at between $£ 10.10$ s and $£ 21$, as was hysterectomy. The price of hysterectomy is especially striking, given that by the 1880 s, ovariotomy was comparatively safer and more established than hysterectomy, which had replaced the former as the most dreaded of abdominal operations. Like ovariotomy, there had been a chequered history of experimentation with hysterectomy from the mid-century onwards. In the early 1880s, the mortality rate for abdominal hysterectomy remained abysmal, around seventy per cent, far worse than for ovariotomy. Primarily this was due to the complex vascular tissues of the uterus which carried a high risk of 
haemorrhage. ${ }^{58}$ The year 1885 had seen a wisp of hope with Thomas Keith's successes with the operation. He reported that of his total of thirty-eight cases he had had only three deaths-the most successful set of hysterectomies yet to be reported. ${ }^{59}$ But the operation remained a fearful prospect, belying the idea that antiseptic and aseptic techniques had acted as some kind of panacea for surgeons who ventured into the abdomen. Even the provocative Robert Lawson Tait, who performed ovariotomy with a certain abandon, quivered at the thought of extirpating the uterus and his mortality rate for the operation reached over thirty-five per cent. This was far beyond any of the other abdominal operations he performed, for which he had achieved some of the lowest mortality rates in the country. ${ }^{60}$ The British Medical Journal paraphrased Tait translating his horror of the operation into tangible, pecuniary terms: 'he has stated...that the amount of worry which is given him by every case of hysterectomy, even when successful, is such as to be almost beyond the recompense of any fee' the journal reported. ${ }^{61}$

De Styrap's tariff acted only as a guide for practitioners who were not at a consultant level. A well-known ovariotomist like Thomas Spencer Wells, or a successful lithotomist such as Henry Thompson remained at liberty to charge what they wished. ${ }^{62}$ Nonetheless the recommendations of The Medico-Chirurgical Tariffs had the respect of the profession and its suggestions were taken seriously in light of there being few other similar works for doctors to look to. De Styrap assured readers that the prices were devised using the advice of specialists in each field rather than based solely on his own estimations (suggesting that an ovariotomist had informed de Styrap's judgment of the operation's price). ${ }^{63}$ The pricing of ovariotomy by de Styrap poses significant questions about how exactly its pecuniary value was determined and why it continued to be deemed the most expensive operation a practitioner could undertake. Undoubtedly, operative risk was one of the key factors in its pricing, although the risk being compensated for was not so much that to the patient's life but that to the surgeon's professional reputation and even their wellbeing. Despite Keith's assertion about the comparative ease of performing ovariotomy by the 1880 s, every performance of it remained mired in risk for the patient. Intertwined with that risk was also a potentially traumatic experience for the surgeon if the operation was difficult or if it failed, and this in itself acted 
as a major constraint upon their choice to operate. A high price, therefore, essentially acted as a form of pecuniary compensation for the anxieties produced by the possible death of a patient and subsequent damage that might be done to one's reputation. As one American surgeon described his experiences with ovariotomy in 1884 , with unusual candour, 'in 1883, 1881 and $1882 \ldots$ my ovariotomies died right off as fast as I could operate upon them. It made me so sick, that I could scarcely bear to hear of a case of ovariotomy'. ${ }^{64}$

The price was also likely inflated by the professional risks specific to those who performed major surgery upon the female reproductive organs. All doctors who specialised in diseases of women were susceptible to charges of misconduct, mistreatment or immodesty. As a consequence, cultivating a professional identity of chivalrous protector to one's delicate female patients was important. ${ }^{65}$ At least three ovariotomists, Isaac Baker Brown, the scandal surrounding whom was discussed in the last chapter, Heywood Smith and Francis Imlach, failed to do so and had their careers brought to virtual ruin by controversies in their practice. Heywood Smith had been revealed in 1886 to have assisted the controversial journalist W. T. Stead in his investigations into child prostitution for the Pall Mall Gazette. Stead had 'purchased' a thirteen-year-old girl as part of his exposé into the trade in young virgins. In an effort to prevent Stead from being accused of sexually assaulting her, Smith had been drafted in to prove the girl's virginity through a vaginal examination, in what was seen by the profession as a flagrantly immoral and unprofessional act; Smith only narrowly avoided expulsion from the Obstetrical Society. ${ }^{66}$ Liverpool surgeon Francis Imlach also received public criticism in 1886 when he was alleged to have removed both ovaries from a woman without her consent, an episode which resulted in legal action, and which will be discussed in more detail in the next section. The financial impact on all three men was catastrophic. Brown, who at the height of his powers had received considerable patronage from the wealthy and elite of London, died virtually penniless, supported in his final years only by the charity of a few sympathetic members of the profession. Smith fared a little better, having managed to resurrect a semblance of a career after the scandal and went on to set up the New Hospital for Women. But his reputation never quite recovered, and he died with a comparably paltry $£ 4232$ to his name. Imlach also died poor, his financial worth at death valued at just $£ 125$. Imlach's annual earnings 
had plummeted from $£ 800$ to $£ 37$ the year after the controversy surrounding his operations, showing just how drastic the financial impact of such an episode could be and how rapidly a carefully built-up practice could disintegrate. ${ }^{67}$ High prices provided at least some form of insurance. By the end of the 1880s some ovariotomists, such as Robert Lawson Tait, had begun to identify themselves as 'abdominal' surgeons. This in part reflected the growing expansion of surgery into the abdomen as splenotomies and nephrotomies began to be performed more frequently, often by those who had made their names as ovariotomists. But arguably the term also allowed practitioners to style themselves as unrestricted by gender, and thus meant their practice was less loaded with the risky sexual politics which specialists in female diseases had frequently to negotiate.

The high price accorded to ovariotomy might also be attributed to another aspect not unrelated to risk, that of the time postoperatively that needed to be spent on a case. De Styrap never specified whether he was factoring in attendance after an operation in his suggested fees, but the considerable aftercare needed following an ovariotomy would have contributed significantly to the overall price. All major operations put demands on a surgeon's time. A lithotomy case in the 1880s, for example, even if the operation was deemed successful, generally required a month of careful attendance afterwards. ${ }^{68}$ A successful ovariotomy was seen to require slightly less time; most hospital patients were ready to leave after around eighteen to twenty-four days, although for those who could afford it, this was usually followed by a stay in a convalescent institution. ${ }^{69}$ However, abdominal operations required a depth of care that extended beyond the remit of most other operations, as surgeons guarded against signs of any of the array of worrying complications that might occur: septic disease, haemorrhage, fistula, intestinal obstruction and so on. If an ovariotomy case became complicated, it could mean months of careful attendance. Much of this care demanded only watchful waiting and dietary regulation on the part of the referring practitioner and nurses, rather than active treatment. But the burden of responsibility remained heavy on the operating surgeon, whose attendance was routinely required. Fears of being accused of concealing poor outcomes in ovariotomy remained prevalent and those who performed it were encouraged to keep abreast of their former patients' condition 
for at least a year after the operation, meaning that every case-in theory at least-required serious investment of a surgeon's time. ${ }^{70}$ Very little was written about the pricing of aftercare following an ovariotomy, other than the Lancet's observation (cited above) that it was the heavy cost of nursing that pushed up the price of the operation. But it seems likely that surgeons often charged separate fees for the operation itself and the aftercare, as the latter's price varied considerably depending on where the patient was convalescing and how frequently their services would be called upon. Charles Clay's preserved case notes, spanning the late 1850 s and early 1860s, while detailing an earlier time period, give an important perspective on this particular financial aspect of the operation. Clay charged between $£ 15$ and $£ 40$ per case, but in his records he often broke these charges down into the constituent parts of the whole process, noting separate fees for 'operation', 'attendance' and on occasion 'lodging' too, all of which required payment. ${ }^{71}$ Taking hysterectomy once more as a comparison, it is unclear why there is a difference in their price in de Styrap's table. Technically speaking, ovariotomy was not any more demanding than hysterectomy; in fact, it was probably less so, and the two operations would have likely involved similar regimes of aftercare. ${ }^{72}$ Furthermore, those who performed hysterectomy were usually ovariotomists first and foremost, thus liable to the same professional risks and responsibilities that might be endured when performing ovariotomy.

This leads one to speculate that the high fees charged for ovariotomy reflected additional factors, one of which may have been its unique identity as a major innovation. It was ovariotomy that had paved the way for making abdominal surgery safe. Yet early ovariotomists had not been rewarded for their innovations, rather they had been interrogated, scorned and derided for performing the operation. For the newer generation revelling in the acceptance ovariotomy had now gained, and its grand status as the operation that had changed the landscape of surgery, high fees were perhaps compensation for the troubles ovariotomists had been put through before the operation had received acclaim.

There was most likely another factor that was also implicated in the continued expense of ovariotomy: the growing number of conditions that it was claimed could be treated by the operation. By the 1880 s, fears were forming in the profession that ovarian surgery was being performed excessively and that women were having their ovaries removed for trivial ailments. As we shall see in the next section, such a possibility not only had professional consequences but financial ones too. 


\section{Oöphorectomy, Operative Mania and Surgical Consumption}

In the 1880s, ovariotomy continued to be the most common operation performed in women's hospitals. As we have seen, with the emergence of Battey's and Tait's operations, described in Chapter 4, there was also a growing interest among surgeons about how removing both ovaries might alleviate certain conditions other than ovarian tumours. ${ }^{73}$ But a backlash against Tait, Battey and their followers was gaining ground, exploding in 1886 in a veritable panic about an apparent 'laparotomy epidemic' which centred almost entirely on the excessive use of ovarian surgery. ${ }^{74}$ Fears were growing that surgeons were overenthusiastically removing ovaries for 'trivial' reasons, most often for mild ovarian pain and inflammatory conditions, and usually in conjunction with the removal of the Fallopian tubes. In the closing weeks of 1885, a scandal began to unfold at the Liverpool Hospital for Women. That year, questions had begun to be raised by colleagues regarding the number of major abdominal operations being performed by one of the hospital's surgeons, Francis Imlach. A paper Imlach had given to the Liverpool Medical Institution in December 1885 had cited forty-one cases of salpingo-oöphorectomy (removal of the ovaries and Fallopian tubes) for pyosalpinx (an accumulation of pus in the Fallopian tube) and ovarian abscesses. Despite a comparatively low mortality rate of seven per cent, Imlach's paper sparked questions from his contemporaries, suspicious of the high numbers of patients he was operating upon. An inquiry was duly set up which revealed a substantial increase in the number of abdominal sections undertaken at the hospital between 1884 and $1885 .{ }^{75}$ Things went from bad to worse for Imlach when an ex-patient and her husband, a Mr. and Mrs. Casey, began a civil action against the surgeon, claiming that the latter had not properly informed them that they would no longer be able to conceive following the removal of both of Mrs. Casey's ovaries. In a case that brought forth many of the pressing questions of the day surrounding ovarian physiology, Mrs. Casey also cited a loss of sexual desire as a result of the operation. ${ }^{76}$ Imlach won the case by the skin of his teeth, after one of the hospital's nurses came forward to claim that she had informed Mrs. Casey of the operation's consequences. But his reputation and his practice were severely compromised. ${ }^{77}$ In 1897 , even greater controversy would be generated by a similar case involving Charles Cullingworth, a surgeon at St. Thomas' Hospital. Cullingworth 
was taken to court by a former patient named Alice Jane Beatty. Beatty, who was a nurse, and thus probably more knowledgeable about medical matters than the average patient, alleged Cullingworth had removed both her ovaries without her consent. Beatty had requested an operation to remove one ovary, explicitly expressing her wish that under no circumstance should the other be removed. In a case which highlighted the fragility of patient consent in the surgical encounter, Cullingworth nonetheless had removed the second ovary, claiming he had found it so ravaged with disease upon opening the abdomen, that it was deemed necessary to remove it immediately. The medical profession was split on their judgment of Cullingworth's actions. Remarkably, given the social pressure exerted upon doctors to support and protect their professional peers, several high-profile practitioners publicly acknowledged that Cullingworth had misjudged the case. They included Thomas Spencer Wells, who was called to give expert evidence in court. While Wells cautiously offered support to Cullingworth, whom he believed had 'acted to the best of his ability', he conceded that the removal of both ovaries had been unnecessary and that Cullingworth had not given due consideration to his patient's wishes. Despite the evidence of Wells and others, the plaintiff Alice Beatty eventually lost the case. ${ }^{78}$ Nonetheless news of it filtered into the public press. ${ }^{79}$ Throughout the last years of the century ovariotomists would remain under intense scrutiny from both the profession and the public about their operating practices.

The fear that hundreds of women's reproductive abilities were being destroyed readily fused with anxieties about degeneration and sterility. That the operation was also, on occasion, being used to treat insanity startled many, even those who were themselves ovariotomists; 'he who cuts mad people must himself be mad' declared Thomas Spencer Wells in his 1886 essay, On the Castration of Women, in which he angrily castigated the propensity of some surgeons to preside over questions of mental disease with their knives. ${ }^{80}$ This trend was not exclusive to ovarian surgery. In the late nineteenth century, castration and, to a much greater extent, circumcision, were both advocated by doctors to treat male patients for a range of diseases from dyspepsia to rheumatism to insanity. ${ }^{81}$ The move towards surgically managing the reproductive organs to treat both physical and mental disease signalled the increasing power of surgeons to monopolise the medical arena. However, ovarian surgery undoubtedly had a much higher profile than male castration and was considered more prevalent. In his essay, Wells questioned whether 
surgeons would castrate or remove the penis from a man for as trivial reasons as those for which he claimed ovaries were being removed. ${ }^{82}$

Crucial to the argument of Wells and others was that the use of ovarian surgery for an increasingly diverse range of conditions did not seem to be based upon any major developments in physiological understandings of the ovary. Rather, it rested upon a growing confidence in the safety of removing ovaries, which allowed surgeons to experiment more readily with already-established ideas about the organ's relation to other bodily ills. ${ }^{83}$ It was this chasm between a relatively static moment in ovarian physiology and the rapid developments occurring in ovarian surgery that hinted at impropriety, echoing previous cases of surgical abuse like that of Isaac Baker Brown and the clitoridectomy operation. Could it be, as some speculated, that pathologies were being invented by surgeons specifically so that they could be cured for a price? ${ }^{84}$ The Medical Press and Circular certainly thought so and waged a high-profile attack on surgeons leading the trend. An Anglo-Irish publication, it's possible that concerns about removing the female reproductive organs assumed greater importance within the predominantly Catholic Irish medical profession. Even before the Imlach affair, the journal had been the most vocal critic within the medical press of the overuse of ovarian surgery, particularly of oöphorectomy and salpingo-oöphorectomy (or 'the removal of the uterine appendages', as the latter procedure was often termed). As early as 1882 the journal had speculated in regard to the operation that 'greed and the predilection engendered by special and limited study are apt to compel men to unravel all forms of disease' ${ }^{85}$ Thus, the journal reiterated the oft-made accusation that 'specialist' practice was more about money than medicine, and bred an unsavoury culture where diseases were invented simply so that they could be profited from.

The Medical Press and Circular revived its attack on oöphorectomy after the revelations about Francis Imlach's practice, but centred its criticism upon Robert Lawson Tait, the bombastic Birmingham surgeon who was evidently loathed by the journal. In 1886, it began to make quite clear in a series of articles its opinion of Tait's practice: that his motivations were pecuniary rather than medical. Tait, an avid correspondent with many of the medical journals, rarely let sleeping dogs lie when allegations were made about him, and retorted angrily when the journal described his practice as one of the 'large centres in which spaying is practised wholesale'. 86 'Spaying' was a derogatory term used to describe 
oöphorectomy by its detractors. Like 'castration', it evoked the idea that women's bodies were being treated as experimental material by doctors in the same vein that animals were. This was a powerful analogy to make at a time when the anti-vivisection movement was flourishing, and narratives of vivisection and ovariotomy were often explicitly brought together by prominent campaigners, who saw both procedures as expressive of cruelty, and the oppression of the weak by medical men. ${ }^{87}$ The Medical Press refused to retract its inferences about the business aspect to Tait's practice. Instead, they plunged the knife in further: 'if he objects to the word "wholesale" he cannot deny that a very large "retail" business of this kind is done in some very large centres', the journal wrote. ${ }^{88}$ Once more Tait responded angrily, claiming that, if anything, his practice in oöphorectomy was costing him money, and described how he had been compelled to provide free beds in his private hospital for scores of women who could not afford to fund themselves. Tait claimed that each such case cost him fifteen to twenty guineas and that the patients who came to him-not wealthy, but not so poor as to secure admittance to a general hospital-had already been drained of their resources. Like Isaac Baker Brown before him, Tait claimed that his patients had spent all their money on trying to find a medical rather than surgical solution to their problem, often leaving them in serious financial straits. ${ }^{89}$

Some saw the apparent enthusiasm for gynaecological surgery as little more than a fashion. Thomas More Madden, an Irish surgeon who worried deeply about the spread of excessive surgery of this kind, made the link explicit in his lecture to the Obstetrical Section of the Academy of Medicine in Ireland, Titled 'On the So-Called Laparotomy Epidemic', which he published in 1886 at the height of the controversy. ${ }^{90} \mathrm{He}$ would go on to expound similar views at the British Medical Association meeting in Brighton the following year. ${ }^{91}$ 'No one acquainted with ancient medical literature will question the continually recurring influence of fashion on medical opinion and practice in every age' he wrote, 'nor can it be gainsaid that in successive epochs various forms of disease and methods of treatment come into and go out of vogue with almost as little reason as influences the ever-changing modes of dress'. ${ }^{92}$ For Madden, there was a certain alarming inevitability to medicine being swayed by trends, something which had to be kept carefully in check. This was not the first time that ovarian surgery had been described as merely a fashion. As we saw in Chapter 3, similar allegations had been made some forty years before when the justifiability of performing ovariotomy at all was debated. ${ }^{93}$ 
As a consequence, surgeons like Thomas Spencer Wells were keen to highlight that oöphorectomy was an entirely different operation from ovariotomy. Ovariotomy had proved its worth; oöphorectomy on the other hand, was an innovation upon the original innovation, and an unwelcome one at that. For those outside of the profession, however, and indeed for many within it, the distinction was not clear-cut; oöphorectomy was simply a new unfolding of ovarian surgery's often unnecessary use. When in 1909 playwright and well-known critic of the medical profession, George Bernard Shaw, addressed the Medico-Legal Society on 'the Socialist Criticism of the Medical Profession', Shaw specifically pinpointed the 'fashion' for operations and in particular, ovariotomy, as a symbol of unnecessary profiteering in medicine. Thus, it was not the more recent controversies surrounding oöphorectomy he alluded to but rather the more 'traditional' ovariotomy, indeed he even referred to Spencer Wells. ${ }^{94}$ Such depictions led not only to the continued characterisation of ovariotomy as a novelty but also exacerbated already present concerns about ovarian surgery as an immoral money-spinner. The phrases increasingly used to describe it, as a vogue, a fashion, an excess, alluded to the possibility of wastefulness and unthinking consumption.

Regardless of whether these accusations had a solid foundation or not, if the notion of a procedure being fashionable held sway, it at once made it vulnerable, removing any veneer of professional neutrality and imbuing it with worldliness; making it as much the product of whimsical fashion as a style of dress. The use of the word 'fashion' was slippery. It suggested a trend among doctors in their proclivities for performing certain operations. But it also raised once more questions about trends in the demand for operations (explored in Chapter 3). For if there was no demand for an operation, how could there be a fashion? Was it possible, then, that women were, at times, active pursuers, consumers even, of ovarian operations? Reflecting back, George Bernard Shaw took this to be the case, implying that fashionable operations like ovariotomy and tonsillectomy attracted 'ladies and gentleman who had heard and read so much about operations that they felt that they could not live without them. Such people are a tremendous temptation to poor doctors'. ${ }^{95}$

Two polarised perceptions of the ovarian patient were emerging in the eyes of critics. On the one end, the vulnerable victim robbed of her reproductive role by unthinking doctors, on the other, the frivolous woman exercising economic power over the practitioner in pursuit 
of an elective operation that put her at unnecessary risk. Both perceptions inhabited dangerous moral ground. This dichotomy has been of interest to historians. Ornella Moscucci has speculated that oöphorectomies may have been sought by some patients as a method of contraception. Certainly as Moscucci suggests, in Britain, practitioners discussed the possibility that oöphorectomy could be extended in its use to produce sterility in women with pelvic deformities as a means of preventing further obstructed labours. ${ }^{96}$ One surgeon also claimed it had become fashionable in Britain for fertile women to seek out methods of becoming sterile, although he did not link this directly to ovarian surgery. ${ }^{97}$ However, in America, where Britons reckoned oöphorectomy to be far more widely performed, the connection was made more explicit. The New York-based journal The Medical Record went as far as suggesting that oöphorectomies were characteristic of a progressive instinct towards population control and could be economically expedient:

No woman wants more than two children, many only one, and a large per cent, including all the unmarried, not any at all. But in fact the population is increasing at a seriously rapid rate, and the modern economist has had to revive and readopt the views of Malthus. In this exigency, when society's needs are antagonised by infant multiplicity, the laparotomist steps in as a kind of modern saviour from the threatened polypedic catastrophe. ${ }^{98}$

This brazen positioning of oöphorectomy as a choice related to lifestyle, and as an operation premised upon social concerns, rather than a medical problem, articulated the deep fears among the profession regarding the normalisation of serious surgery. ${ }^{99}$ Indeed the debate foreshadowed those which continue today about the ethics of elective surgery; especially in regard to female sterilisation, which remains a contentious issue, particularly when it involves women of reproductive age. ${ }^{100}$ Such comments also require us to examine closely how the female patient was positioned within this dialogue, as the recipient of the surgical operation on offer. Certainly notions of demand in ovarian surgery should always be considered in conjunction with risk, which in the 1880s had dropped significantly but remained at a level where a prospective patient would still likely be very concerned: somewhere between five to fifteen per cent of British patients undergoing ovarian surgery died as a result of their operation. ${ }^{101}$ We can presume, therefore, that anxieties about operating would have been as prevalent then as they are today and probably much more so. ${ }^{102}$ Chiefly, critics of the operation were more concerned about lack 
of consent or understanding on the part of the patient, than they were about patient demand. But as Regina Morantz-Sanchez and Claire Brock have both argued, even the possibility of surgery-by-choice had a significant impact on practitioners; the very notion of it suggested a disempowering of doctors and an increase in the authority of female patients. As Brock argues, it was once more the question of necessity that was central; that an operation might principally be carried out because of a patient's request rather than as a consequence of the surgeon's judgment served only to undermine the idea that the operation was-medically speaking-necessary at all. ${ }^{103}$

These concerns manifested themselves in press reports throughout the 1880s and 1890s. The Hospital, a medical magazine with a popular lay readership reported with incredulity a medical society meeting, where "Two cases were related, in both of which it appeared the patients "insisted on the abdomen being opened"... Where is to be the limit of what a medical man will do at the request of a patient?' inquired the journal. ${ }^{104}$ Articles in the Medical Press and Circular in particular, emphasised flippancy on the part of patients undergoing oöphorectomy, and included extracts of patients' accounts of their condition. One editorial detailed the case of a woman about to have her ovaries removed by an anonymous operator. Found by an observer to have 'full round rosy cheeks and red lips', under close questioning the patient revealed she suffered pain only three or four days a month. The operation did not go ahead. ${ }^{105}$ The Medical Press also published a piece by the surgeon Andrea Rabagliati which pondered the justifiability of oöphorectomy. In an article that was to be reprinted in many other journals, Rabagliati reported the case of a consultant friend who:

...had been consulted as to the advisability of removing the uterine appendages in a lady who was said to suffer frightfully. On coming downstairs, the three doctors met the lady's husband, and the consultant said to him, 'is your wife, do you think, suffering more than usual?" "Well, yes" said the husband, "but she has always suffered a good deal". "Has she been confined to bed?" "Oh no!" "How often has she been out this last week?" "Well, we were three times out for dinner, and twice at the theatre!" The consultant turned and looked at the doctors and said nothing!"106

The reference to the couple's glamorous social life was not coincidental. An important class aspect was at work here. The quick fix of an oöphorectomy for painful conditions was believed to have greater worth when 
applied to working-class women who had heavier domestic and occupational duties to contend with-although implicit in this may have been a judgment on the part of surgeons about the relative worth of reproduction among rich and poor women. ${ }^{107}$ Middle-class women, on the other hand, were seen as having less need to resort to such measures, as they generally had more time and greater financial resources to continue with palliative treatments. Thus, the performance of the operation upon richer women was particularly at risk of appearing lavish: evocative of the idea of women as consumers, desirous of commodities and services that would ease their life, regardless of consequences. In France, in 1909, a caricature appeared of Paris' most fashionable ovariotomist, Samuel Pozzi, (Fig. 5.2) which reflected these anxieties. Pozzi, who was gynaecological surgeon at l'hôpital Broca, and who counted John Singer Sargent and Sarah Bernhardt among his friends, was a leading light in a field of practice that was considerably smaller in France than it was in Britain and America. ${ }^{108}$ Nonetheless Pozzi was equally susceptible to allusions regarding the fashionable nature of his work. The caricature, probably published by the Académie Nationale de Médecine, shows the dapper Pozzi dangling two 'o's, representing the ovaries, from an épée. Behind him stand three female figures that appear to be shop mannequins, one of whom, dressed in finery, is labelled 'sterile' or 'sterility'. The cartoon implies the gradual lifelessness of women following the procedure and the removal of their 'natural' function, but also hints at the consumption of surgical services among fashionable women. It was a perception that increasingly became infused with turn-of-the-century ideas of women as frivolous, and signalled complex power relations between the sexes, in which women wielded considerable economic power but always as part of a social framework built around the values and preferences of men. ${ }^{109}$ It was within this nexus that the high price of ovarian surgery was constructed; a financial relationship which saw practitioners at liberty to charge what they wanted, dependent only upon competition from other practitioners, and where patients, it was alleged, were pursuing the operation.

How far this was actually the case, that women were indeed allowing themselves to be operated on 'merely' because of minor discomforts brought to their lives by suspected ovarian disease, or even because they wished to make reproductive choices, is difficult to know, the dearth of 


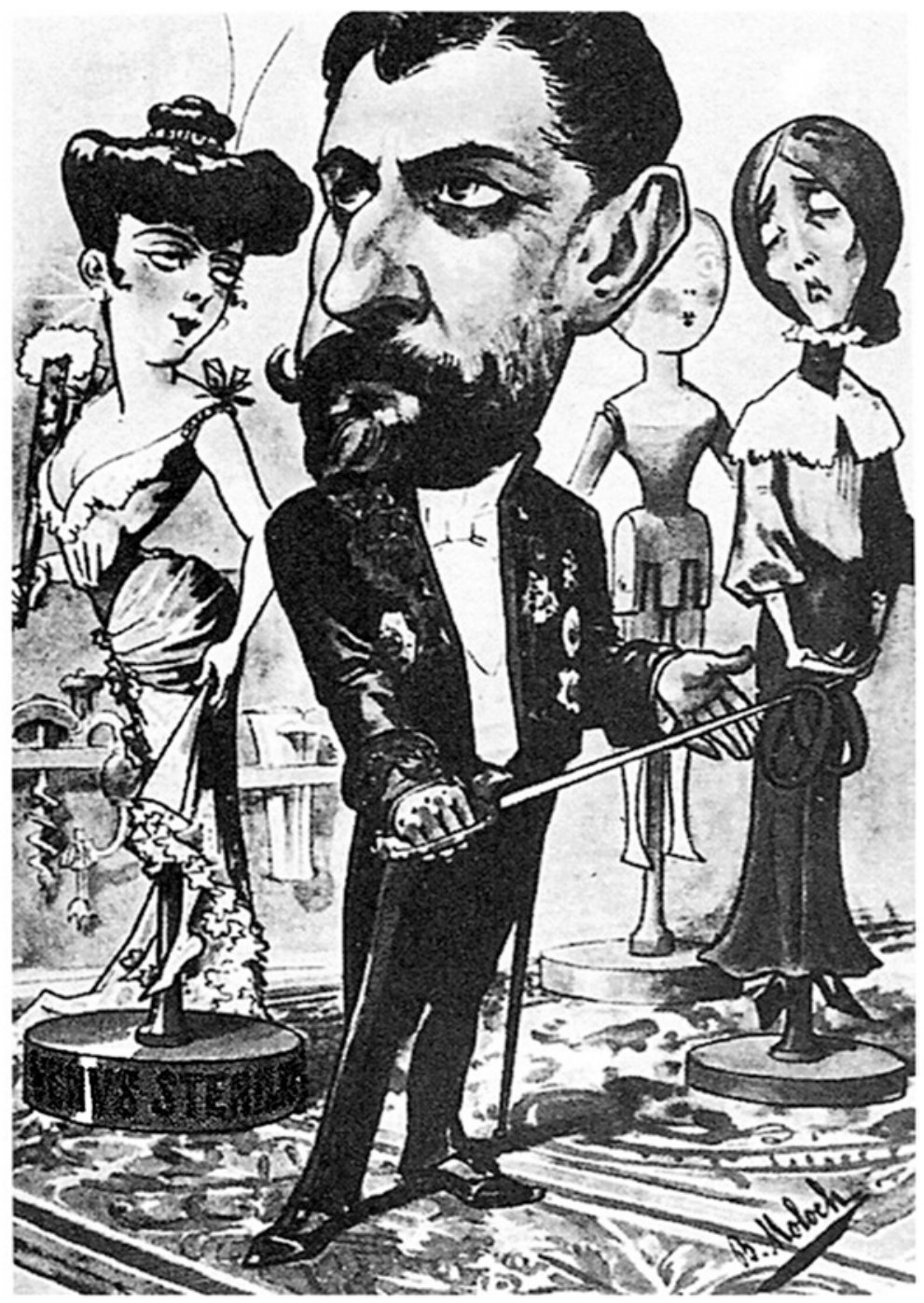

Fig. 5.2 Caricature of the Parisian ovariotomist Samuel Pozzi by the cartoonist Hector Moloch (Alphonse Hector Colomb), 1909 (Credit Private collection of Nicolas Bourdet) 
female patients' accounts proving here as it does in so many areas of the history of medicine to limit our understanding of the patient experience. But the idea that this was happening was sufficient enough to be played upon by critics of oöphorectomy, who sprinkled their protest pieces with anecdotes to suggest such a trend was occurring. The possibility of female patients as economic actors, their desires acquiesced to by unscrupulous operators, provoked considerable consternation. It served to reaffirm anxieties that both the invention and expansion of ovarian surgery were motivated by profit.

\section{CONCLUSION}

A number of historians have drawn attention to the significant economic implications of ovariotomy. But perhaps none have situated them where they should be: central and absolutely integral to the history of the operation, where the potential financial value of the procedure framed its performance and its representation, and where gender, choice, consumerism and consent were tightly bound together. Ovarian surgery was identified as an innovation of private practice and specialist institutions, both of which suggested financial motivations for the operation. At this time, medical specialists were still on shaky ground in regard to their professional standing, particularly those who specialised in the diseases of women. Yet to become an elite practitioner in ovariotomy also potentially paved the way for a lucrative career because 'ovariotomists' were virtually at liberty to charge what they wanted.

The judgment of Jukes de Styrap in his influential The MedicoChirurgical Tariffs that ovariotomy was the most expensive operation in surgery raises questions about how exactly operative value was determined. While conceptions of risk played a fundamental part, as did the level of commitment that would be required from a surgeon after an operation was performed, so too, perhaps, did a sense of entitlement among ovariotomists. The high price reflected the operation's status as a striking and major innovation. Indeed, even as other equally risky operations began to be practised, such as hysterectomy, it was ovariotomy which was deemed the most expensive operation a surgeon could perform. Its price can also be read in terms of a broader commodification of the operation. During the 1880s, there were widespread concerns about a 'fashion' for ovarian surgery. Ovariotomy and oöphorectomy were permanently informed by a male perspective; male surgeons for the 
most part organised and executed the operations, and the vulnerability of women against the onslaught of oöphorectomy in particular was a key concern during the so-called 'laparotomy epidemic'. Yet conversely, the use of ovarian surgery for an increasingly diverse range of conditions also raised the spectre of consumer power, of the possibility that women were purchasing risky surgery simply for a more comfortable life, something, according to critics, that unscrupulous practitioners were willing to acquiesce to in their quest to make money. What becomes clear by looking at the financial aspects to ovariotomy is that historians must venture beyond the explicitly commercial when looking at business and medicine in the nineteenth century. Ovariotomists did not sell patent medicines or advertise in newspapers but, in the eyes of some in the medical community, their services were as much a commercial enterprise as those who did.

In the late nineteenth century, no surgeon who worked in ovarian surgery outwardly claimed that the lucrative nature of the speciality was what motivated them to operate. Such an assertion would have been unpalatable in that medico-cultural context. Nor is it possible to definitively ascertain what did motivate the individual historical actors at play here. The point is that financial issues surrounding ovarian surgery had to be negotiated with great care. That it was lucrative was a double-edged sword; the prices were higher, but so were the stakes. Ovariotomy, still conceived of as a recent innovation, came with its own peculiar risks and responsibilities. Moreover, as new controversies arose with the 'laparotomy epidemic', the possibility that ovarian surgery was an unseemly novelty once more emerged. As we will see in the next chapter, the status of ovarian surgery was not necessarily becoming clearer, in fact it was to become considerably more complex.

\section{Notes}

1. John Gregory, Observations on the Duties and Offices of a Physician, and on the Method of Prosecuting Enquiries in Philosophy (London: W. Strahan and T. Cadell, 1770). Gregory observed that medicine could be 'considered either as an art the most beneficial and important to mankind, or as a trade by which a considerable body of men gain their subsistence', 9 .

2. G.R. Searle, Morality and the Market in Victorian Britain (Oxford: Clarendon Press, 1998), 123-124. As Michael Brown has described 
it, 'by the mid-nineteenth century, English medicine and its associated cultural forms had been undoubtedly and irrevocably transformed'. Michael Brown, Performing Medicine: Medical Culture and Identity in Provincial England, c. 1760-1850 (Manchester and New York: Manchester University Press, 2011), 226.

3. Anne Digby, Making a Medical Living: Doctors and Patients in the English Market for Medicine, 1720-1911 (Cambridge: Cambridge University Press, 1994), 6.

4. Sally Wilde, The History of Surgery: Trust, Patient Autonomy, Medical Dominance and Australian Surgery, 1890-1940 (Byron Bay: Finesse Press, 2010), 99-100.

5. Lori Loeb, 'Doctors and Patent Medicines in Modern Britain: Professionalism and Consumerism', Albion: A Quarterly Journal of British Studies 33, no. 3 (2001): 404-425; Takahiro Ueyama, Health in the Marketplace: Professionalism, Therapentic Desires, and Medical Commodification in Late-Victorian London (Palo Alto: The Society for the Promotion of Science and Scholarship, 2010). In their explorations of the use of patent medicines in doctors' practices, Loeb and Ueyama have both helped dispel the idea that qualified practitioners and patent medicine vendors were operating in distinct spheres.

6. As Christopher Herbert has eloquently remarked on Victorian attitudes to money, 'writers of the day insistently described their society as a great many-layered system of occluded awareness, one in which not knowing what one knew became almost the defining principle of consciousness, at least in the sphere of middle-class life'. Christopher Herbert, 'Filthy Lucre: Victorian Ideas of Money', Victorian Studies 44, no. 2 (2002): 186.

7. Anonymous letter quoted in Howard A. Kelly, 'Conservatism in Ovariotomy', Journal of the American Medical Association 26, no. 2 (1896): 251 .

8. See for example M.W. Weatherall, 'Making Medicine Scientific: Empiricism, Rationality, and Quackery in Mid-Victorian Britain', Social History of Medicine 9, no. 2 (1996). Weatherall argues that during this time 'the advancement of medical knowledge was to become concentrated in a few medical schools and hospitals', 180.

9. Guenter B. Risse, Mending Bodies, Saving Souls: A History of Hospitals (Oxford: Oxford University Press, 1999), 387.

10. Christopher Lawrence and Richard Dixey, 'Practising on Principle: Joseph Lister and the Germ Theories of Disease', in Medical Theory, Surgical Practice: Studies in the History of Surgery, ed. Christopher Lawrence (London and New York: Routledge, 1992), 156. 
11. On modifications in Lister's own principles and practice, see Lawrence and Dixey, 'Practising on Principle'.

12. Lawrence and Dixey, 'Practising on Principle', 153-154.

13. William MacCormac, Transactions of the International Medical Congress, Volume 2 (London: J.W. Kolckmann, 1881), 370-371.

14. Thomas Keith, 'Results of Ovariotomy Before and After Antiseptics', British Medical Journal 2, no. 929 (19 October 1878): 591.

15. In 1883 at the London Hospital for example, only six ovariotomies were performed. See 'Surgery Beadle's Return of Operations Performed' (1883) LH/M/3/7 (Royal London Hospital Archives). However at other general hospitals, such as King's College Hospital, surgeons continued to avoid abdominal surgery completely. Joseph Lister's house surgeon St. Clair Thomson recorded in his memoirs that during Joseph Lister's time at King's (between 1877 and 1892) 'I never saw him do an abdominal section. During my term of office, we never heard the word 'appendicitis'; gastric ulcers were diagnosed but never treated surgically; ovarian cysts were tapped and tapped until the patient died; that a calculus could be removed from a ureter or a bile-duct never entered the imagination of the wildest dreamer'. St. Clair Thomson, 'Memories of a House Surgeon', Lancet 209, no. 5406 (9 April 1927): 777. Unsubstantiated rumours suggested that ovariotomy was unofficially banned from the hospital at this time; see Berkeley Moynihan, 'Lister as Surgeon', Lancet 209, no. 5406 (9 April 1927): 747.

16. Peter D. Mohr, 'Clay, Charles (1801-1893)', in Oxford Dictionary of National Biography (Oxford University Press, 2004), Online edn, October 2006, http://www.oxforddnb.com/view/article/5558, accessed 13 April 2018.

17. Keith, 'Results of Ovariotomy', 590; Robert Lawson Tait, 'Removal of the Uterine Appendages', Medical Press and Circular 42, no. 2471 (1886): 203; Myrrha Bantock, Granville Bantock: A Personal Portrait (London: J.M. Dent, 1972), 27.

18. 'David Lloyd Roberts', Lancet 196, no. 5067 (9 October 1920): 767.

19. M. Anne Crowther and Marguerite W. Dupree, Medical Lives in the Age of the Surgical Revolution (Cambridge: Cambridge University Press, 2007), 196. At the Samaritan Hospital, virtually every surgeon ever connected to the institution continued their links with it until they retired from hospital practice.

20. For an overview on this see Lindsay Granshaw, "Fame and Fortune by Means of Bricks and Mortar": The Medical Profession and Specialist Hospitals in Britain 1800-1948', in The Hospital in History, ed. Lindsay Granshaw and Roy Porter (London and New York: Routledge, 1989), 199-220. Some also viewed specialist hospitals as detrimental to medical 
education, as they stole cases away from general hospitals, thus depriving medical students of experience when walking the wards.

21. James O'Flanagan, Contradiction! Or English Medical Men and Manners of the Nineteenth Century (London: Baillière, Tindall and Cox, 1866), 52 .

22. Morell Mackenzie, 'Medical Specialism', Fortnightly Review 38, no. 224 (1885): 267.

23. Ornella Moscucci, The Science of Woman: Gynaecology and Gender in England 1800-1929 (Cambridge University Press, 1990), 171.

24. Although the term 'ovariotomist' had first appeared in the medical press in the 1850s. It is not entirely clear who coined the term, although it is possible that like 'ovariotomy' it was Charles Clay, who often used the term to describe himself.

25. Many London ovariotomists were closely associated with the Royal College of Surgeons of England and other London surgical societies. Wells was President of the College in 1882. His assistant both in private practice and at the Samaritan Hospital, Alban Doran, was connected to the College's Hunterian Museum throughout his career.

26. Thomas Schlich, "The Days of Brilliancy Are Past": Skill, Styles and the Changing Rules of Surgical Performance, ca. 1820-1920', Medical History 59, no. 3 (2015): 402-403.

27. King's College Hospital surgeon William Watson Cheyne was described rather politely as 'not a brilliant operator', while Walter Rivington, senior surgeon at the London Hospital was allegedly perceived as a 'poor operator by colleagues'. 'William Watson Cheyne', in Plarr's Lives of the Fellows, vol. 3, ed. D'Arcy Power (London: Royal College of Surgeons, 1997), 145; Stephen Trombley, Sir Frederick Treves (Routledge, London and New York, 1989), 12.

28. 'Obituary-Alban Henry Griffiths Doran', British Journal of Obstetrics and Gynaecology 34, no. 3 (1927): 547.

29. 'Royal Medical and Chirurgical Society, Tuesday November 11th 1862', Lancet 80, no. 2047 (22 November 1862): 569.

30. The American Practitioner and News reported that Robert Lawson Tait, who along with Thomas Spencer Wells was probably the British ovariotomist of greatest renown in America, charged from 'five guineas to one hundred for an ovariotomy'. 'Notes and Queries', The American Practitioner and News 3 (1887): 224. Guineas were no longer a form of currency by this time, having been replaced in 1816 by the pound. However 'guinea' was still used to refer to a payment of twenty-one shillings (around $£ 70$ in today's money). The term was thought to give transactions an air of refinement and was popularly used by doctors when charging fees. 
31. 'Within the Hospital Walls: A Matter of Fact Narrative', Lancet 127, no. 3277 (19 June 1886): 1202.

32. 'Notes and Queries', The American Practitioner and News 16 (1877): 59.

33. Moscucci, The Science of Woman, 170.

34. R.V. Jackson, 'The Structure of Pay in Nineteenth-Century Britain', Economic History Review 40, no. 4 (1987): 563.

35. 'Within the Hospital Walls: A Matter of Fact Narrative', 1202. In her popular volume, Lectures on General Nursing (1884), London Hospital matron Eva Lückes warned nurses of the careful and exacting care that would be expected from those looking after ovariotomy cases, which was 'one of the most important operations of which you can ever have charge'. Eva Lückes, Lectures on General Nursing (London: Kegan Paul, 1884), 133.

36. 'Within the Hospital Walls: A Matter of Fact Narrative', 1202. Acting as a nurse in ovariotomy cases was considered difficult work and both those employed in public and private institutions were expected to spend many hours watching over their patients. Ideally one or two specialist nurses were appointed to a case. 'Nursing Echoes', Nursing Record 1, no. 25 (1888): 337.

37. Keith, 'Results of Ovariotomy', 593.

38. Regina Morantz-Sanchez also addresses the impact of ovariotomy's daring and bold nature as a means of explaining resistance to the operation by many American surgeons; Regina Morantz-Sanchez, Conduct Unbecoming of a Woman: Medicine on Trial in Turn-of-the-Century Brooklyn (Oxford: Oxford University Press, 1999), 92.

39. Proceedings at the Seventh Annual Meeting of the London Surgical Home (London: Savill \& Edwards, 1865), 34. Lawson Tait used a similar argument when his motives for performing oöphorectomy were questioned. Tait, 'Removal of the Uterine Appendages', 202-203.

40. Charles K. Harley, 'Trade, 1870-1939: From Globalisation to Fragmentation', in Cambridge Economic History of Modern Britain, Vol. 2: Economic Maturity, 1860-1939, ed. Roderick Floud and Paul Johnson (Cambridge: Cambridge University Press, 2004), 168.

41. Overcrowding in the medical profession was a perpetual source of anxiety among doctors throughout the nineteenth century. Historians have tended to focus on the middle decades when, as Irvine Loudon has argued, the expansion of the middle classes and an increase in graduates from the Scottish medical schools were believed to have increased the number of practitioners vying for positions. This led to deepening stigmatisation of irregular practitioners and growing anxieties about competition, that were in part expressed through the establishment of the 1858 Medical 
Act; Irvine Loudon, Medical Care and the General Practitioner (Oxford: Clarendon Press, 1986), 208-227.

42. 'The Prospects of the Profession', Medical Press and Circular 40, no. 2420 (1885): 257.

43. Keir Waddington, Medical Education at St. Bartholomew's Hospital, 1123-1995 (Woodbridge: The Boydell Press, 2003), 299.

44. Despite the concern many doctors had that the profession was overcrowded, statistics compiled by Walter Rivington in 1888 in his exhaustive account of the state of the medical profession during the late nineteenth century suggested that proportionally there was a decline in the number of doctors within the general population between 1851 and 1881 . Walter Rivington, The Medical Profession of the United Kingdom (Dublin: Fannin \& Co, 1888), 2. This was also picked up on by the British Medical Journal, 'Review: The Medical Profession of the United Kingdom', British Medical Journal 1, no. 1474 (30 March 1889): 717-718.

45. The lithotomist Henry Thompson, a surgeon renowned for his polymathic bent and cultivation of fine tastes in art and literature, commented in one of his pseudonymous novels that it is not a curious fact, for it is an indispensable one, that almost every medical man of ordinary intelligence, who achieves a fair share of success in his profession-and unluckily the taste sometimes exists without success enough to warrant its cultivation-becomes a fine art collector of some sort, and has a hobby, which when you know him, and not until then, you are perhaps astonished to discover'. Pen Oliver (Henry Thompson), Charley Kingston's Aunt (London: Macmillan, 1885), 14.

46. Digby, Making a Medical Living, 193.

47. In a publication in 1879, the Manchester Medico-Ethical Association wrote that it was 'convinced that the subject of medical charges must ever remain a somewhat open one, so long as the profession, unlike all other trades and professions, continues to claim its remuneration not according to the abstract worth of its services alone, but also according to the ability of its clients'. Manchester Medico-Ethical Association, Tariff of Medical Fees Issued by the Manchester Medico-Ethical Association (Manchester: J. E. Cornish, 1879), 3.

48. 'Consultation-Fees', British Medical Journal 2, no. 923 (7 September 1878): 376. See also 'Physicians, Practitioners, Patients and Fees', British Medical Journal 1, no. 889 (12 January 1878): 56-57.

49. 'Consultation-Fees', British Medical Journal 2, no. 927 (5 October 1878): 539.

50. Manchester Medico-Ethical Association, Tariff of Medical Fees, 10. The tariff's only concession to this was to include the Poor Law's scale of surgical fees as a guide to minimum charges. 
51. 'Professional Fees', British Medical Journal 1, no. 737 (13 February 1875): 223. Some physicians expressed admiration for surgeons for charging such disparate fees, as it directly opposed the uniform guinea-fee payment they were subjected to.

52. Jukes de Styrap, A Code of Medical Ethics (London: J. \& A. Churchill, 1878).

53. Jukes de Styrap, The Medico-Chirurgical Tariffs (Prepared for the Late Shropshire Ethical Branch of the British Medical Association) (London: H. K. Lewis, 1890).

54. The Edinburgh Medical Journal noted that de Styrap's pamphlet 'did not profess to be a guide as to how the wealthy should be charged by their ordinary attendant, or how consultants should estimate the value of their own services'. 'Review: The Medical-Chirurgical Tariffs', Edinburgh Medical Journal 34, no. 1 (1888): 62.

55. 'Review: The Medical-Chirurgical Tariffs', 62.

56. Steve Sturdy and Roger Cooter, 'Science, Scientific Management, and the Transformation of Medicine in Britain c. 1870-1950', History of Science 36 (1998): 422.

57. De Styrap, The Medico-Chirurgical Tariffs, 20-27. For the highest socio-economic class listed, de Styrap suggested between 315 and 610 shillings could be charged for a caesarean section.

58. For a detailed discussion of uterine surgery in the nineteenth century, see Ilana Löwy, “Because of Their Praiseworthy Modesty, They Consult Too Late": Regime of Hope and Cancer of the Womb, 1800-1910', Bulletin of the History of Medicine 85, no. 3 (2011): 356-383. Statistical studies of hysterectomy mortality rates were sparse around this time as so few were being performed. But a table of 365 hysterectomies performed by surgeons across the world, compiled by American surgeon Theodore Gaillard in 1880, put the mortality rate of hysterectomy at seventy per cent; Theodore Gaillard, A Practical Treatise on the Diseases of Women (London: Henry Kimpton, 1880), 547. By the end of the 1880 s, vaginal as well as abdominal hysterectomy was being practised, although this too had a high mortality rate. De Styrap does not specify which method of hysterectomy he is referring to.

59. Thomas Keith, 'Thirteen Cases of Hysterectomy, With Remarks on Carbolic Acid Spray in Abdominal Surgery', British Medical Journal 1, no. 1257 (31 January 1885): 214; 'Editorial: Ovariotomy, Hysterectomy and Oöphorectomy', British Medical Journal 1, no. 1257 (31 January 1885): 240.

60. Lawson Tait, 'Abstract of an Address on One Thousand Abdominal Sections', British Medical Journal 1, no. 1257 (31 January 1885): 218.

61. 'Editorial: Ovariotomy, Hysterectomy and Oöphorectomy', 240. 
62. Thompson was well-known for commanding huge fees for his services, spurred on by the prestige he had garnered from treating King Leopold of Belgium for bladder stones in 1863. Zachary Cope notes that in 1865, Thompson earned $£ 2000$ for treating a high-ranking British Admiral in Paris. Zachary Cope, The Versatile Victorian: Being the Life of Sir Henry Thompson, 1820-1904 (London: Harvey \& Blythe, 1951), 45.

63. De Styrap, The Medico-Chirurgical Tariffs, 4.

64. 'Essay on Desperate Surgery in Its Relation to Women: The Proper Place for It; Who Should and Who Should Not Attempt It', Journal of the American Medical Association 3, no. 12 (20 September 1884): 322.

65. Ornella Moscucci, 'Clitoridectomy, Circumcision and the Politics of Sexual Pleasure in Mid-Victorian Britain', in Sexualities in Victorian Britain, ed. Andrew H. Miller and James Eli Adams (Bloomington: Indiana University Press, 1996), 75-76.

66. 'Obstetrical Society of London', Lancet 127, no. 3258 (6 February 1886): 255-256. Stead was well-known for his crusade against child prostitution. This case, however, in which Stead had attempted to 'buy' a child prostitute, was considered scandalous and led to his conviction for child abduction.

67. J.J. Rivlin, 'Francis Imlach (1851-1920) and the Liverpool Medical Establishment', Medical Historian (1999): 48. All probate information cited is taken from the UK index of probate records at www.ancestry. com.

68. William Cadge, 'Lithotomy', in Dictionary of Practical Surgery, vol. 1, ed. Christopher Heath (London: Smith, Elder \& Co., 1889), 937.

69. John Knowsley Thornton, 'Ovariotomy', in Dictionary of Practical Surgery, vol. 2, ed. Christopher Heath (London: Smith, Elder \& Co., 1886), 158.

70. Alban Doran, Handbook of Gynaecological Operations (Philadelphia: P. Blakiston \& Son, 1887), 271. The American ovariotomist Edmund Peaslee claimed to have rejected over 100 ovariotomy cases on the basis that he wouldn't be able to adequately oversee their aftercare, writing in 1867 that the after-treatment of an operation constituted 'three fourths the responsibility, and nine-tenths the anxiety'. Edmund Peaslee, 'Ovariotomy, When and How to Operate; After-Treatment', Southern Journal of the Medical Sciences 2 (1867): 551.

71. Charles Clay's case book, M/C Medical Collection-cat.9.11.54 MNB (Manchester Medical Collection, University of Manchester).

72. Keith, 'Results of Ovariotomy', 593.

73. As seen in the operative statistics of the Samaritan Free Hospital, where between 1878 and 1897, of the 1643 abdominal sections undertaken at the hospital, exactly 1000 were ovarian operations. Hysterectomies 
comprised just 163 of the procedures. Alban Doran, 'Classification of Abdominal Sections in Index Form, 187-1897' (c. 1924) MSO155/2/2 (Royal College of Surgeons of England).

74. The terms oöphorectomy and laparotomy tended to be used interchangeably in this context. Technically laparotomy was any incision into the abdomen, but the 'laparotomy epidemic' almost always referred to procedures where the ovaries, often in conjunction with the Fallopian tubes, were being removed. The rapidly changing terminology in operative surgery will be explored in more detail in the next chapter.

75. J.J. Rivlin, 'Francis Imlach', 44; 'Editorial', Lancet 128, no. 3285 (14 August 1886): 304-307. Imlach's colleague Thomas Grimsdale stated that the number of abdominal sections at the hospital in 1884 was 44 , compared to 111 in 1885 .

76. Whether women lost their sexual desire after having both ovaries removed was one of the biggest issues of the oöphorectomy debate. Lawson Tait was always adamant that this was not the case and publicly supported Imlach throughout the episode. Robert Lawson Tait, 'Casey vs Imlach', Lancet 128, no. 3286 (21 August 1886): 375.

77. Rivlin, 'Francis Imlach', 48-49.

78. Claire Brock, 'Risk, Responsibility and Surgery in the 1890s and Early 1900s', Medical History 57, no. 3 (2013): 330-333.

79. 'Remarkable Action Against a London Surgeon', Sheffield and Rotherham Independent, no. 13150 (17 November 1896): 8; 'Action Against a Doctor', Dundee Courier and Argus, no. 13537 (17 November 1896): 4; 'Nurse v. Doctor: A Claim for Damages', Hampshire Telegraph and Sussex Chronicle, no. 6010 (21 November 1896), 2.

80. Thomas Spencer Wells, Modern Abdominal Surgery: The Bradshaw Lecture Delivered at the Royal College of Surgeons of England December 18th, 1890 with an Appendix on the Castration of Women (London: J. \& A. Churchill, 1891), 49. On the Castration of Women was originally published in America in 1886 but Wells insisted on republishing it in 1891.

81. Robert Darby, A Surgical Temptation: The Demonization of the Foreskin and the Rise of Circumcision in Britain (Chicago and London: University of Chicago Press, 2005), 10-11.

82. Wells, Modern Abdominal Surgery, 47.

83. For example, the connection between the ovaries and hysteria was intimated earlier in the century in the physiological writings of Thomas Laycock; Thomas Laycock, A Treatise on the Nervous Diseases of Women (London: Longman, Orme, Brown, Green and Longmans, 1840), 144 . 
84. Henry Coe of the Women's Hospital in New York was reported by the Medical Press and Circular to have remarked that a peculiarity in the growth of abdominal surgery was that it owes its impetus to the surgeons rather than to the pathologists'. 'The Frequency of Diseases of the Uterine Appendages', Medical Press and Circular 42, no. 2463 (1886): 30 .

85. 'Editorial: Questionable Surgery', Medical Press and Circular 33 (1882): 385 .

86. 'The Frequency of Disease of the Uterine Appendages', 31.

87. Mary Ann Elston, 'Women and Anti-Vivisection in Victorian England, 1870-1900', in Vivisection in Historical Perspective, ed. Nicolaas A. Rupke (London and New York: Routledge, 1990), 278-279. Although interestingly, Tait himself vehemently opposed vivisection.

88. 'The Frequency of Disease of the Uterine Appendages', Medical Press and Circular 42, no. 2464 (1886): 58.

89. 'Removal of the Uterine Appendages', 203. In Tait's case the accusation may have been unfair. As Regina Morantz-Sanchez has shown, Tait was known for using money he earned from treating rich patients to fund his work with the poor. Morantz-Sanchez, Conduct Unbecoming of a Woman, 152.

90. Thomas More Madden, 'On the So-Called Laparotomy Epidemic', Dublin Journal of Medical Science 82, no. 1 (1886): 2.

91. Thomas More Madden, 'Observations on Removal of the Uterine Appendages', British Medical Journal 1, no. 1358 (8 January 1887): 52-54.

92. Madden, 'On the So-Called Laparotomy Epidemic', 2.

93. 'Extirpation of Ovarian Tumors', Medico-Chirurgical Review 40 (1 April 1844): 557.

94. 'I cannot believe that all the ovariotomies that were performed after Spencer Wells found out how to do it were necessary', George Bernard Shaw, 'The Socialist Criticism of the Medical Profession', Transactions of the Medico-Legal Society 6 (1909): 216.

95. Shaw, 'The Socialist Criticism of the Medical Profession', Transactions, 216-217. Tonsillectomy was performed with increasing frequency in the early twentieth century. See Sally Wilde, The History of Surgery: Trust, Patient Autonomy, Medical Dominance and Australian Surgery, 18901940 (Byron Bay: Finesse Press, 2010), 79.

96. Moscucci, The Science of Woman, 149.

97. Thomas M. Dolan, 'Gynaecological Specialism and General Practice', British Gynaecological Journal 5, no. 19 (1889): 296.

98. 'The Usefulness of Spaying', Medical Record 29, no. 15 (1886): 419. As quoted in the Medical Press and Circular. 'Editorial: The Virtues of 
Laparotomy', Medical Press and Circular 41, no. 2457 (1886): 502503. 'Polypedic' referred to multiple children.

99. 'Editorial: The Virtues of Laparotomy', 502-503. See also Mary J. HallWilliams, Ovariotomy Averted (Plymouth, 1899).

100. Holly Brockwell, 'Why Can't I Get Sterilised in My 20s?' The Guardian (28 January 2015), http://www.theguardian.com/commentisfree $/ 2015 /$ jan/28/why-wont-nhs-let-me-be-sterilised\#comment-46773414, accessed 11 December 2017.

101. By 1883, the mortality rate at the Samaritan Hospital in London was about one in eighteen. Not all surgeons were able to claim such results, though. In 1887, the surgeon Charles Cullingworth, who would shortly after move from Manchester to take up a position at St. Thomas' Hospital in London, reported that he had lost $13.5 \%$ of his thirty-seven ovariotomy patients during the first half of the 1880s. Thomas Spencer Wells, 'An Inaugural Address on the Revival of Ovariotomy, and Its Influence on Modern Surgery', Lancet 124, no. 3194 (15 November 1884): 857; Charles Cullingworth, 'A Tabular Statement of Sixty-Four Abdominal Sections; Including Forty-Five Completed Ovariotomies with Remarks', Lancet 130, no. 3335 (30 July 1887): 205.

102. Patients' anxiety about undergoing an operation remains virtually universal. E. Carr et al., 'Patterns and Frequency of Anxiety in Women Undergoing Gynaecological Surgery', Journal of Clinical Nursing 15, no. 3 (2006), 341-352.

103. Brock, 'Risk, Responsibility and Surgery', 330.

104. 'The Patient Insisted Upon Abdominal Section!', The Hospital 23 (12 March 1898): 412.

105. Morantz-Sanchez, Conduct Unbecoming of a Woman, 106-107; Editorial response to correspondence from Robert Lawson Tait, Medical Press and Circular 42, no. 2471 (1886): 203.

106. Andrea Rabagliati, 'Notes on Abdominal Section for Ovariotomy, Oophorectomy, and Hysterectomy', Medical Press and Circular 41, no. 2455 (1886): 445.

107. Morantz-Sanchez, Conduct Unbecoming of a Woman, 50. MorantzSanchez cites the American experience specifically, but contemporary reports suggest a similar attitude prevailed in Britain. In 1879 Heywood Smith wrote 'Where a patient is able to afford to lie up and have every appliance for the relief of pain, when, at the same time, her general health is not suffering much, she might be advised to wait and tide over the time till the menopause. But when a patient is poor and dependent upon others who are equally poor, when her sufferings extend over at least three weeks out of every four, when she is quite unable to earn her living, and when she prefers running a certain amount of risk to 
continuing in her wretched and useless state, then we are bound to listen to her pleading, and do what improved science places in our power to do to relieve pain'. Heywood Smith, 'Successful Case of Battey's Operation or Oöphorectomy’, British Medical Journal 2, no. 967 (1879): 42.

108. On Samuel Pozzi, see Caroline de Costa and Francesca Miller, The Diva and Doctor God: Letters from Sarah Bernhardt to Doctor Samuel Pozzi (Bloomington: Xlibris, 2010).

109. Judith Walkowitz, City of Dreadful Delight: Narratives of Sexual Danger in Late Victorian London (Chicago: University of Chicago Press, 1992), 48; see also Mary Louise Roberts, 'Review Essay: Gender, Consumption and Commodity Culture', American Historical Review 103, no. 3 (1998): 817-844.

Open Access This chapter is licensed under the terms of the Creative Commons Attribution 4.0 International License (http://creativecommons.org/licenses/ by $/ 4.0 /)$, which permits use, sharing, adaptation, distribution and reproduction in any medium or format, as long as you give appropriate credit to the original author(s) and the source, provide a link to the Creative Commons license and indicate if changes were made.

The images or other third party material in this chapter are included in the chapter's Creative Commons license, unless indicated otherwise in a credit line to the material. If material is not included in the chapter's Creative Commons license and your intended use is not permitted by statutory regulation or exceeds the permitted use, you will need to obtain permission directly from the copyright holder.

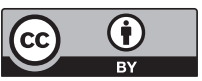

